\title{
Uptake of urea and amino acids by the macroalgae Ulva lactuca (Chlorophyta) and Gracilaria vermiculophylla (Rhodophyta)
}

\author{
Anna Christina Tyler ${ }^{1,2, *}$, Karen J. McGlathery ${ }^{1}$, Stephen A. Macko ${ }^{1}$ \\ ${ }^{1}$ Department of Environmental Sciences, University of Virginia, PO Box 400123, Charlottesville, Virginia 22903, USA \\ ${ }^{2}$ Present address: Department of Environmental Science and Policy, University of California - Davis, One Shields Avenue, \\ Davis, California 95616, USA
}

\begin{abstract}
Dissolved organic nitrogen (DON) makes up a large fraction of the total dissolved nitrogen pool in coastal waters, but is often ignored as a potential nitrogen source for primary producers. In laboratory experiments, we measured the uptake of small, labile DON compounds, urea and a variety of different amino acids, by the common estuarine macroalgae Ulva lactuca and Gracilaria vermiculophylla. Urea uptake was measured based on its disappearance from solution; amino acid uptake was measured using this method as well as by assimilation of ${ }^{15} \mathrm{~N}$ - and ${ }^{13} \mathrm{C}$-labeled amino acids. The Michaelis-Menten uptake parameters $\left(K_{\mathrm{m}}, V_{\max }, V_{\max } / K_{\mathrm{m}}\right)$ were calculated for all compounds. Whereas both species were capable of assimilating urea and amino acids, U. lactuca consistently exhibited significantly higher uptake rates than G. vermiculophylla. There were 2 distinct phases of uptake for urea, an initially rapid 'surge' uptake phase and a slower, 'sustained' phase. This suggests that both species can take advantage of pulsed urea availability. $V_{\max }$ rates for urea for $U$. lactuca were lower than published values for ammonium uptake, but were still high enough to be a significant factor at natural urea concentrations. We did not observe surge uptake of amino acids by either species and the uptake rates varied substantially among the 6 amino acids studied. The differential uptake of ${ }^{15} \mathrm{~N}$ and ${ }^{13} \mathrm{C}$ by $U$. lactuca suggested that both alanine and glycine are decarboxylated prior to uptake. However, following decarboxylation, the residual of the glycine molecule is assimilated, while the amine group on alanine is likely removed prior to assimilation. Glycine uptake rates by $\mathrm{N}$-starved or $\mathrm{NH}_{4}{ }^{+}$-fertilized macroalgae were higher than uptake rates by $\mathrm{NO}_{3}{ }^{-}$-fertilized macroalgae, which suggests that the induction of glycine and ammonium uptake may be similar. The low half-saturation constant $\left(K_{\mathrm{m}}\right)$ and the high affinity at low concentrations $\left(V_{\max } / K_{\mathrm{m}}\right)$ that we measured for amino acids suggests that macroalgae can take advantage of the low concentration of amino acids found in estuarine waters. This study shows that macroalgae are capable of utilizing DON and that under conditions of low inorganic nitrogen availability, organic nitrogen may provide a significant portion of the total $\mathrm{N}$ demand.
\end{abstract}

KEY WORDS: Marine macroalgae $\cdot$ Organic nitrogen $\cdot$ Nitrogen uptake $\cdot$ Urea $\cdot$ Amino acids $\cdot$ Ulva · Gracilaria

Resale or republication not permitted without written consent of the publisher

\section{INTRODUCTION}

Primary productivity in temperate estuaries is often limited by nitrogen (N) availability (Howarth 1988). Dissolved inorganic nitrogen (DIN) uptake by benthic macroalgae, important primary producers in shallow estuaries (Smith 1981, Sand-Jensen \& Borum 1991, Valiela et al. 1997), is fairly well-understood, but relatively little is known about the uptake of common dissolved organic nitrogen (DON) compounds, such as urea and free amino acids (Lobban \& Harrison 1997, $\mathrm{p}$ 179). Indeed, most studies investigating nutrient 
uptake by and nutrient limitation of aquatic plants have focused on DIN, while DON, although long acknowledged as an important component of the total dissolved N pool in marine waters (Sharp 1983), has largely been ignored as a potential $\mathrm{N}$ source. This bias may be due to the anthropogenically enhanced levels of DIN in well-studied temperate estuaries or perhaps to the ease of measurement of specific inorganic compounds $\left(\mathrm{NH}_{4}{ }^{+}\right.$and $\left.\mathrm{NO}_{3}{ }^{-}\right)$relative to specific organic compounds (e.g. urea, amino acids). However, in recent years the importance of DON in fulfilling the nitrogen demand for both aquatic and terrestrial plants has been more fully recognized (e.g. Antia et al. 1991, Chapin et al. 1993, Chisholm et al. 1996, Turnbull et al. 1996, Berg et al. 1997, Mulholland et al. 1998, Nasholm et al. 1998). Indeed, in a shallow estuary in Virginia, where water column concentrations and sediment-water column fluxes of DON often exceeded that of DIN, small labile organic N compounds such as amino acids and urea provided a substantial proportion of the $\mathrm{N}$ demand for macroalgae, particularly at very low DIN concentrations (Tyler et al. 2003).

Given the high turnover rate of urea in the water column, urea may be a substantial contributor to phytoplankton $\mathrm{N}$ demand in the ocean (Cho et al. 1996), and may also be important seasonally in estuaries (Bronk \& Glibert 1993), or for specific estuarine bloom-forming species (e.g. Lomas et al. 1996, Glibert et al. 2001). Fluxes of urea from the sediments to the water column can also be substantial (Boucher \& Boucher-Rodoni 1988, Lomstein et al. 1989, 1998, Tyler et al. 2001); in shallow estuaries this flux may be an important source of $\mathrm{N}$ for benthic macroalgae (Tyler et al. 2003) and for phytoplankton. When DIN availability is low, urea may provide the majority of the $\mathrm{N}$ demand for macroalgae (Tyler et al. 2003). While growth rates of macroalgae fertilized with urea-N can be equivalent to those with DIN (Probyn \& Chapman 1982, Thomas et al. 1985, Navarro-Angulo \& Robledo 1999), there have been few studies of urea uptake kinetics in macroalgae (Probyn \& Chapman 1982).

In low-nutrient waters, dissolved free amino acids (DFAA) also may represent a significant source of $\mathrm{N}$ to primary producers, even though DFAA make up a small percentage of the dissolved $\mathrm{N}$ pool in seawater (Sharp 1983). It is well demonstrated that planktonic and benthic microalgae are capable of DFAA uptake (Admiraal \& Peletier 1979, Macko \& Green 1982, Admiraal et al. 1984, Flynn \& Butler 1986, Antia et al. 1991, Nilsson \& Sundback 1996). Phytoplankton may assimilate some amino acid $\mathrm{N}$ via an extracellular mechanism, whereby DFAA in the water column are split into $\mathrm{NH}_{4}{ }^{+}, \mathrm{H}_{2} \mathrm{O}_{2}$ and organic acids by cell-surface deaminating enzymes, and the $\mathrm{NH}_{4}{ }^{+}$is subsequently taken into the cell (Palenik \& Morel 1990a,b, Pantoja \& Lee 1994). In low-nutrient waters, assimilation by this mechanism may contribute up to $10 \%$ of the total $\mathrm{NH}_{4}{ }^{+}$ taken up by phytoplankton (Mulholland et al. 1998). There have been no similar studies of the mechanisms of DFAA uptake by macroalgae, and few estimates of potential utilization or kinetic uptake parameters for DFAA exist (Schmitz \& Riffarth 1979).

In order to test whether uptake of urea and amino acids contributes significantly to total $\mathrm{N}$-uptake in estuarine macroalgae, we examined DFAA and urea uptake by 2 common species, Gracilaria vermiculophylla (Ohmi) Papenfuss (Rhodophyta) and Ulva lactuca L. (Chlorophyta), and estimated the MichaelisMenten kinetic uptake parameters under different environmental conditions (light and $\mathrm{N}$ availability). We also used ${ }^{15} \mathrm{~N}$ - and ${ }^{13} \mathrm{C}$-labeled amino acids to explore the mechanism of DFAA uptake in these macroalgae.

\section{MATERIALS AND METHODS}

Macroalgae for the uptake experiments were collected from a mid-lagoon site in Hog Island Bay, Virginia, USA, during the summers of 1999 and 2000. Hog Island Bay, part of the Virginia Coast Reserve Long Term Ecological Research (LTER) site, is a small $\left(100 \mathrm{~km}^{2}\right)$, shallow $(50 \%$ is $<1 \mathrm{~m}$ at mean low water), back-barrier lagoon extending westward from the Delmarva Peninsula. Total dissolved $\mathrm{N}$ in Hog Island Bay ranges from 4.8 to $30.0 \mu \mathrm{M}$. Of the total dissolved $\mathrm{N}$ pool, amino acids make up 0 to $3 \%(0.02$ to $0.43 \mu \mathrm{M})$ and urea constitutes 2 to $10 \%(0.2$ to $2.3 \mu \mathrm{M}$; Tyler et al. 2003). Together, Ulva lactuca and Gracilaria vermiculophylla, an invasive macroalga from the Western Pacific, make up $>80 \%$ of the total macroalgal biomass in the Bay (M. Thomsen et al. unpubl. data) and are generally found as loose mats. We base the identification of $U$. lactuca on Humm (1979); and G. vermiculophylla on recent molecular and morphological studies (Gurgel \& Fredericq 2004, Rueness 2005, F. Gurgel pers. comm.). Macroalgae were returned to the laboratory in Charlottesville, Virginia and acclimated for 7 to $10 \mathrm{~d}$ in an environmental growth chamber (Conviron ${ }^{\mathrm{TM}}$ ) at $20^{\circ} \mathrm{C}$ and a light intensity of $550 \mu \mathrm{E} \mathrm{m}^{-2} \mathrm{~s}^{-1}$ (16 h light, $8 \mathrm{~h}$ dark). These temperature and light conditions were maintained during the uptake experiments. During the acclimation period, macroalgae were maintained in shallow plastic tubs containing 61 of low nutrient seawater $\left(\mathrm{NH}_{4}{ }^{+}=0\right.$ to $2 \mu \mathrm{M}_{i} \mathrm{NO}_{3}{ }^{-}=0.2$ to $0.5 \mu \mathrm{M}$; urea $=$ 0.2 to $0.8 \mu \mathrm{M}$; DFAA $=50$ to $270 \mathrm{nM}$ ) collected from Machipongo Inlet, where the Atlantic Ocean enters Hog Island Bay. The water was continuously bubbled with air to ensure adequate water movement and aeration, and was changed every 2 to $3 \mathrm{~d}$. 
For each uptake experiment individual thalli (0.05 to $0.2 \mathrm{~g}$ dry weight [dw]) were incubated in $125 \mathrm{ml}$ Erlenmeyer flasks containing 80 to $100 \mathrm{ml}$ filtered $(0.2 \mu \mathrm{m})$ seawater and an antibiotic treatment (10 ppb ampicillin, 100 ppb erythromycin) to prevent bacterial mineralization of organic compounds and subsequent uptake of mineralized $\mathrm{N}$ by the macroalgae. A separate study showed that the antibiotic decreased bacterial cells by $>75 \%$ over untreated incubations ( $t$-test, $p=0.01$ based on acridine orange direct counts of bacteria) and had no significant effect on macroalgal production ( $t$-test, $\mathrm{p}=0.2$, Tyler 2002). Water 'blanks', with antibiotics but no added macroalgae, were run simultaneously with all experiments where uptake was estimated from the loss of $\mathrm{N}$ from solution; a significant decrease in urea or amino acid concentrations was never observed in these blanks. The flasks were gently shaken to ensure adequate mixing and prevent the build-up of a boundary layer at the thallus surface. At the conclusion of each experiment, thalli were removed from the flasks, rinsed $3 \times$ in fresh, filtered seawater and $1 \times$ in nanopure water, patted dry, frozen and freeze-dried. Dry weights were obtained, and where appropriate, thalli for carbon, nitrogen and stable isotope analysis were ground to homogeneity using an electric coffee mill. The calculations used to determine uptake and the Michaelis-Menten parameters are described below (see 'Calculations').

Urea uptake. The duration of the 'surge' uptake phase for urea, the period of rapid uptake during the first minutes of exposure, was measured for both Gracilaria vermiculophylla and Ulva lactuca in experiments at an initial urea concentration of approximately $8 \mu \mathrm{M}$ with samplings at very short time intervals $(0$, $0.5,1,2,3,4,6,8,10,12,15$ and $20 \mathrm{~min})$. Comparisons were made between $\mathrm{N}$-starved and N-replete macroalgae $(n=5)$. During the acclimation period prior to the experiments, N-replete macroalgae received sufficient $\mathrm{N}$ to maintain a tissue content of $2.5 \% \mathrm{~N}$ at an estimated growth rate of $10 \% \mathrm{~d}^{-1} ; \mathrm{N}$-starved macroalgae received no additional nutrients. The fertilization increased the N content of $G$. vermiculophylla by $\sim 25 \%$ (unfertilized $=2.02 \%$, fertilized $=2.46 \%$ ), but only by $\sim 15 \%$ for $U$. lactuca (unfertilized $=1.49 \%$, fertilized $=$ $1.72 \%)$, probably because of higher growth rates for U. lactuca.

Michaelis-Menten parameters were estimated for urea uptake by Ulva lactuca over a $30 \mathrm{~min}$ period using 6 initial concentrations $(\mathrm{n}=5)$, ranging from 3 to $17 \mu \mathrm{mol}$; samples were taken at $0,2,5,10,20$ and 30 min. Kinetic uptake parameters were estimated separately for 'surge' and 'sustained' phases.

The effects of $\mathrm{NH}_{4}^{+}$and light intensity on urea uptake by both Gracilaria vermiculophylla and Ulva lactuca were examined in a $2 \times 2 \times 2$ factorial experi- ment ( $\mathrm{n}=5$ ), with 2 levels of light during the $10 \mathrm{~d}$ acclimation period (low $\approx 50 \mu \mathrm{mol}$ photons $\mathrm{m}^{-2} \mathrm{~s}^{-1}$ and high $\approx 550 \mu \mathrm{mol}$ photons $\mathrm{m}^{-2} \mathrm{~s}^{-1}$ ), 2 combinations of $\mathrm{N}$ during the experiments (Urea only and Urea $+\mathrm{NH}_{4}{ }^{+}$), and 2 levels of light during $\mathrm{N}$ exposure (light and dark) when the uptake parameters were estimated. Five replicates of each combination of nutrients, acclimation light and experimental light were used for each species. Initial urea and $\mathrm{NH}_{4}{ }^{+}$concentrations were 10 and $15 \mu \mathrm{M}$, respectively. Samples were taken 0, 10, 30, 60,100 and 150 min after addition of macroalgae. A 3-way ANOVA was performed separately on initial and sustained uptake rates for each species separately. A 1-way ANOVA was performed on pooled data to compare overall rates between the 2 species.

Amino acid uptake. The uptake of specific amino acids (AA) by Ulva lactuca and Gracilaria vermiculophylla was measured using ${ }^{15} \mathrm{~N}$ - and ${ }^{13} \mathrm{C}$-labeled amino acids (Isotec, Sigma Aldrich). For each experiment, 3 small thalli ( 0.1 to $0.2 \mathrm{~g} \mathrm{dw}$ ) were sampled for the initial $\delta^{15} \mathrm{~N}$ and $\delta^{13} \mathrm{C}$ values and unless otherwise noted, 3 replicate thalli for each species and treatment were used for all of the AA uptake experiments. The ability to take up and assimilate AA ${ }^{15} \mathrm{~N}$ was measured for neutral (glycine [GLY], alanine [ALA] and aminobutyrate [ABU]), acidic (aspartic acid [ASP] and glutamic acid [GLU]) and basic (serine [SER]) amino acids. These amino acids were chosen to represent the variety of amino acids present in Hog Island Bay. Thalli were exposed to initial concentrations of $0.2,0.5,1.5$, 5 and $10 \mu \mathrm{M}$ AA-N for $30 \mathrm{~min}$. The thalli were then prepared for stable isotope analysis.

In order to validate the ${ }^{15} \mathrm{~N}$ uptake method, we compared uptake of ALA and $\mathrm{NH}_{4}{ }^{+}$, separately and in combination, using the ${ }^{15} \mathrm{~N}$ method and using the traditional method based on the disappearance of the nutrient from solution for both species. Initial concentrations were 5 and $15 \mu \mathrm{M}$ of ALA and $\mathrm{NH}_{4}{ }^{+}$, respectively. ALA and $\mathrm{NH}_{4}{ }^{+}$concentrations were measured prior to macroalgal addition and 1, 5, 10, 15 and $30 \mathrm{~min}$ after addition. Thalli were removed from solution and prepared for stable isotope analysis after $30 \mathrm{~min}$. Total uptake was calculated between 0 and $30 \mathrm{~min}$, with an adjustment for the removal of each sample volume. The relationship between the 2 methods was analyzed using a linear least squares regression. This experiment also allowed us to evaluate 'surge' uptake of ALA during the first minutes of exposure as well as the impact of $\mathrm{NH}_{4}{ }^{+}$on ALA uptake. The differences in ALA uptake in the presence and absence of $\mathrm{NH}_{4}{ }^{+}$, and vice versa, were evaluated using a 1-way ANOVA.

The effects of light or dark and $\mathrm{N}$ status on AA uptake rates were also measured for both species. Thalli (1 to $2 \mathrm{~g}$ wet weight [ww]) were held overnight under ambient light or in complete darkness and then 
were incubated in separate flasks (light or dark) containing a solution of $9.1 \mu \mathrm{M}$ GLY. At $0.5,2$ and $4 \mathrm{~h}$ after initial exposure to GLY, 6 thalli of each species (3 light, 3 dark) were removed from solution and processed as described previously. Differences in the uptake rate between light and dark were evaluated using a 1-way ANOVA for each species.

To test for the effect of $\mathrm{N}$ status on AA uptake, macroalgae fertilized with $\mathrm{NH}_{4} \mathrm{Cl}, \mathrm{NaNO}_{3}$ or nothing for $10 \mathrm{~d}$ were used. The fertilization rate was sufficient to sustain an approximate growth rate of $5 \% \mathrm{~d}^{-1}$ and a tissue $\mathrm{N}$ content of $4 \%$. The actual tissue $\% \mathrm{~N}$ values at the time of the experiment for the low $\mathrm{N}_{1} \mathrm{NH}_{4}{ }^{+}$and $\mathrm{NO}_{3}{ }^{-}$treatments were $2.1 \pm 0.1,4.6 \pm 0.1$ and $4.1 \pm 0.2$ for Ulva lactuca and $2.5 \pm 0.1,4.9 \pm 0.1$ and $3.1 \pm 0.1$ for Gracilaria vermiculophylla, respectively. Uptake rates for both ALA and GLY were measured at an initial concentration of $5 \mu \mathrm{M}_{i}$ thalli were removed after $30 \mathrm{~min}$ and processed as described above. Statistical differences between uptake rates were identified using a 1-way ANOVA with Tukey's HSD post-hoc test.

Simultaneous assimilation of amino acid carbon (C) and $\mathrm{N}$ was estimated for both the $\mathrm{C}_{1}$ (carboxyl carbon) and $\mathrm{C}_{2}$ (central carbon) atoms of GLY and ALA in order to gain insight into the mechanism of AA assimilation by macroalgae. We chose these AA because ALA is active and GLY is inactive in the cell-surface amino acid oxidase system of phytoplankton (Palenik \& Morel 1990a). Thalli were exposed to solutions containing $50 \%{ }^{15} \mathrm{~N}^{12} \mathrm{C}_{1}{ }^{12} \mathrm{C}_{2}$ and $50 \%{ }^{14} \mathrm{~N}^{13} \mathrm{C}_{1}{ }^{12} \mathrm{C}_{2}$ or $50 \%{ }^{14} \mathrm{~N}$ ${ }^{12} \mathrm{C}_{1}{ }^{13} \mathrm{C}_{2}$ for $30 \mathrm{~min} . \mathrm{C}_{2}$ uptake was measured at initial concentrations of $0.2,0.5,1.5,5$ and $10 \mu \mathrm{M}_{i} \mathrm{C}_{1}$ uptake was measured only at an initial concentration of $5 \mu \mathrm{M}$. The relationship between the uptake of ${ }^{15} \mathrm{~N}$ and the uptake ${ }^{13} \mathrm{C}_{2}$ was analyzed using linear regression. The slope of the resulting line and the ratio of ${ }^{15} \mathrm{~N}$ uptake: ${ }^{13} \mathrm{C}_{1}$ uptake were evaluated based on their similarity to the slope or ratio expected if both atoms were assimilated simultaneously.

Nutrient analyses. Ammonium was measured using the phenol-hypochlorite method (Solorzano 1969). Urea was measured using a modification of the methods described by Mulvenna \& Savidge (1992) and Goeyens et al. (1998). ALA was measured by pre-column derivatization with $o$-phthaldialdehyde, separation by HPLC using a 2-eluent gradient (Eluent 1: $80 \% \mathrm{NaAc}$ buffer, 19\% HPLC grade methanol, $1 \%$ tetrahydrofuran; Eluent 2: $80 \%$ HPLC grade methanol, $20 \%$ NaAc buffer; Gilson 231 Autosampler and 401 Dilutor; Dionex 4000 Gradient Pump; Alltech Guard Column and Adsorbosphere OPA HR Separator Column), and detection by fluorescence (St. John's Associates Fluorescence detector; Jones et al. 1981). Tissue $\mathrm{N}$ and C concentrations and ${ }^{15} \mathrm{~N}$ and ${ }^{13} \mathrm{C}$ abundances were measured using a Carlo Erba CNS Elemental Analyzer coupled to a GV Optima stable isotope ratio mass spectrometer at the University of Virginia.

Calculations. Uptake rates $\left(V\left[\mu \mathrm{mol} \mathrm{gdw}^{-1} \mathrm{~h}^{-1}\right]\right)$ for urea, ALA and $\mathrm{NH}_{4}{ }^{+}$based on the disappearance of the substrate from solution were calculated for each time interval according to:

$$
V=\frac{X_{\mathrm{i}}-X_{\mathrm{f}}}{t \times B}
$$

where $X_{\mathrm{i}}$ and $X_{\mathrm{f}}$ are the initial and final quantities in $\mu \mathrm{mol}$ of substrate in solution, $t$ is time in hours and $B$ is the dry weight of the algal thallus. In order to obtain the kinetic uptake parameters representing the maximum uptake rate $\left(V_{\max }\right)$ and the half saturation constant $\left(K_{\mathrm{m}}\right)$ for each nutrient, the Michaelis-Menten function was fitted to the relationship between $V$ and the mean substrate concentration, $S$ (in $\mu \mathrm{M}$ ), for each time interval using non-linear, least-squares regression according to:

$$
V=\frac{V_{\max } \times S}{K_{\mathrm{m}}+S}
$$

An estimate of the uptake affinity for each nutrient at low substrate concentrations was obtained based on the initial slope of the $V$ versus $S$ curve, defined as $V_{\max } / K_{\mathrm{m}}$ (Healy 1980). Uptake of ${ }^{15} \mathrm{~N}$-labeled AA and $\mathrm{NH}_{4}{ }^{+}$were calculated according to:

$$
V=\frac{\left(\mathrm{N}_{\mathrm{f}} \times \text { atom } \%{ }^{15} \mathrm{~N}_{\mathrm{f}}\right)-\left(\mathrm{N}_{\mathrm{i}} \times \text { atom } \%{ }^{15} \mathrm{~N}_{\mathrm{i}}\right)}{\text { atom } \%{ }^{15} \mathrm{~N}_{\text {sol }} \times t}
$$

where $\mathrm{N}_{\mathrm{f}}$ and $\mathrm{N}_{\mathrm{i}}$ are the final and initial tissue $\mathrm{N}$ content in $\mu \mathrm{mol} \mathrm{g} \mathrm{dw}{ }^{-1}$, atom $\%{ }^{15} \mathrm{~N}_{\mathrm{f}}$ and atom $\%{ }^{15} \mathrm{~N}_{\mathrm{i}}$ are the final and initial tissue atom percentages, and atom $\%{ }^{15} \mathrm{~N}_{\mathrm{sol}}$ is the ${ }^{15} \mathrm{~N}$ content of the solution. $\mathrm{N}_{\mathrm{f}}$ and $\mathrm{N}_{\mathrm{i}}$ were calculated as the sum of the tissue ${ }^{14} \mathrm{~N}_{\mathrm{i} \text { or } \mathrm{f}}$ and ${ }^{15} \mathrm{~N}_{\mathrm{i} \text { or f }}$, which were calculated as the product of the total tissue $\mathrm{N}_{\mathrm{i} \text { or } \mathrm{f}}\left(\mathrm{gN} \mathrm{gdw}{ }^{-1}\right)$ and the atom $\%{ }^{14} \mathrm{~N}_{\mathrm{i} \text { or } \mathrm{f}}$ or atom $\%{ }^{15} \mathrm{~N}_{\mathrm{i} \text { or f }}$, respectively. The average substrate concentration (in $\mu \mathrm{M}$ ) over the time interval was calculated by averaging the initial substrate concentration and the initial concentration less the calculated amount of substrate taken up for each thallus (corrected for the volume of liquid in the flask).

\section{RESULTS}

\section{Urea uptake}

Because there were no significant differences in tissue $\mathrm{N}$ content, or in the uptake rates between the $\mathrm{N}$ starved and N-replete treatments, we pooled the data for our analysis. Ulva lactuca had a substantially higher rate of urea uptake than Gracilaria vermiculophylla during the first $5 \mathrm{~min}$, with rates $>100 \mu \mathrm{mol}$ 


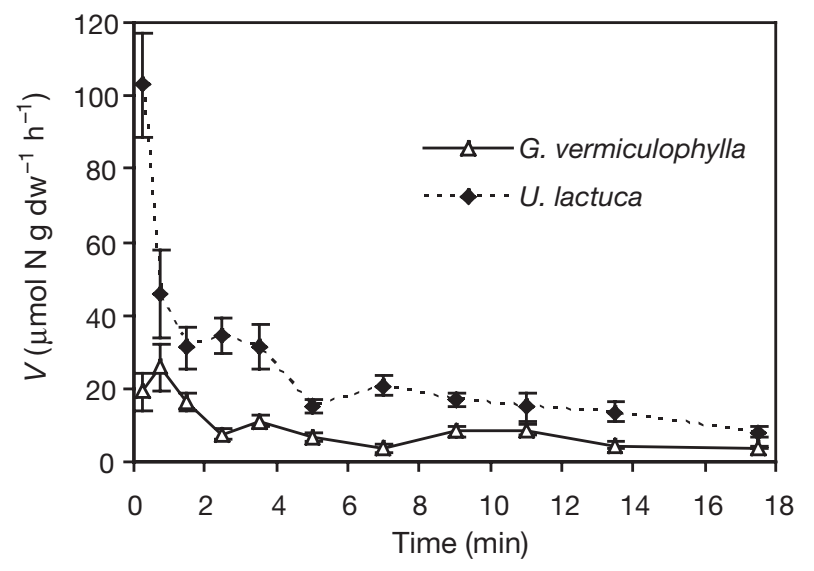

Fig. 1. Ulva lactuca and Gracilaria vermiculophylla. Urea uptake rates $(V \pm \mathrm{SE})(\mathrm{n}=10)$. Time is the halfway point between samplings

$\mathrm{g} \mathrm{dw}^{-1} \mathrm{~h}^{-1}$ in the first $30 \mathrm{~s}$ after exposure to urea (Fig. 1). The maximum uptake rate measured for $G$. vermiculophylla was approximately $25 \mu \mathrm{mol} \mathrm{g} \mathrm{dw}^{-1}$ $\mathrm{h}^{-1}$, during the interval between 1 and $2 \mathrm{~min}$, but there was substantial variability in this measurement. For both species, the uptake rate decreased to a sustained rate between 5 and $15 \mathrm{~min}\left(\sim 15\right.$ to $20 \mu \mathrm{mol} \mathrm{g} \mathrm{dw}^{-1} \mathrm{~h}^{-1}$

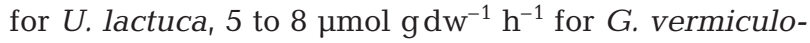
phylla) and decreased to $8 \mu \mathrm{mol} \mathrm{gdw}^{-1} \mathrm{~h}^{-1}$ for $U$. lactuca and $4 \mu \mathrm{mol} \mathrm{g} \mathrm{dw}^{-1} \mathrm{~h}^{-1}$ for G. vermiculophylla between 15 and $20 \mathrm{~min}$. A 1-way ANOVA on uptake rates measured between 0 and $2 \mathrm{~min}$ and 10 to $20 \mathrm{~min}$ was highly significant for both species $(p<0.001)$. Based on these results, we believe that the most reliable estimates for 'surge' and 'sustained' uptake are estimated at 0 to $2 \mathrm{~min}$ and after 15 to $20 \mathrm{~min}$, respectively, following initial exposure.

The Michaelis-Menten uptake curves created from uptake rates by Ulva lactuca measured at different concentrations of urea ( $V$ versus $S$ ) were different for surge (0 to $2 \mathrm{~min}$ ) and sustained (20 to $30 \mathrm{~min}$ ) uptake (Fig. 2). $K_{\mathrm{m}}$ was similar for surge and sustained uptake, but the sustained $V_{\max }$ was $33 \%$ of the surge $V_{\max }$, with a similar decrease in the value of $V_{\max } / K_{\mathrm{m}}$ (Table 1 ).

We measured higher urea uptake during the initial phase ( 0 to $10 \mathrm{~min})$ in the light than in the dark ( $F=5.7$, $\mathrm{p}=0.02$ ) and higher sustained (30 to $150 \mathrm{~min}$ ) uptake rates in the presence of $\mathrm{NH}_{4}{ }^{+}(F=6.25, \mathrm{p}=0.014)$ for Ulva lactuca, but no other significant effects or interactions were found. Because of the short duration of surge uptake observed during the previous experiments, we do not feel that the values measured during the 0 to 10 min interval adequately represent surge uptake and have used the term 'initial' instead. The data were pooled for each treatment and are shown in Table 2. Again, U. lactuca demonstrated significantly

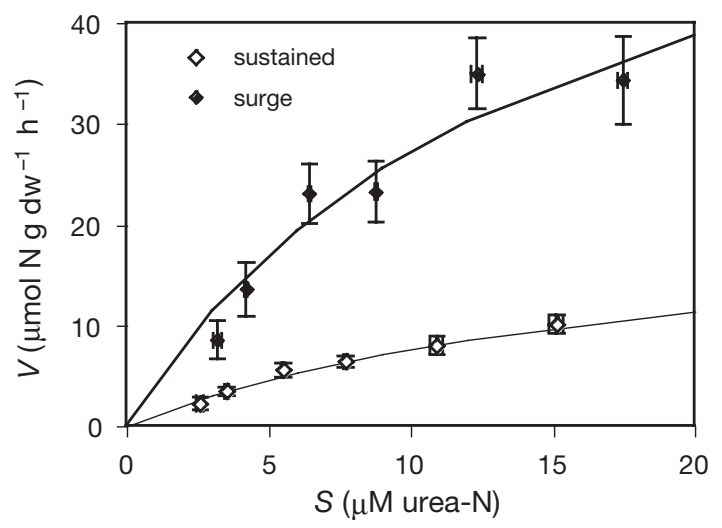

Fig. 2. Ulva lactuca. Surge (0 to $2 \mathrm{~min}$ ) and sustained (after $30 \mathrm{~min})$ uptake rates of urea $(V)$ as a function of urea concentration $(S)$. Least-squares regression lines, based on the

kinetic uptake parameters shown in Table 1, are shown

greater uptake rates than Gracilaria vermiculophylla during both the initial $(F=28.4, \mathrm{p}<0.0001)$ and sustained $(F=149.1, \mathrm{p}<0.0001)$ phases (Table 2$)$.

\section{Amino acid uptake}

AA uptake rates were higher for Ulva lactuca than for Gracilaria vermiculophylla. There was high variability in uptake rates among the different amino acids (Fig. 3, Table 3). When uptake rates were very low, the uptake parameters could not be reliably estimated using least-squares non-linear regression; we have included the maximum measured uptake rate as an estimate of the potential $V_{\max }$ for these amino acids (Table 3). Maximum uptake rates were highest for the aliphatic neutral amino acids GLY and ALA i however, the lowest rate was also measured for an aliphatic neutral amino acid, ABU. SER, an aliphatic hydroxy amino acid, was intermediate and the acidic amino acids, ASP and GLU, had the lowest rates. Overall, $V_{\max }$ was highest for GLY for both species (U. lactuca $5.7 \mu \mathrm{mol} \mathrm{g} \mathrm{dw^{-1 }}$ $\mathrm{h}^{-1}$, G. vermiculophylla $1.8 \mu \mathrm{mol} \mathrm{g} \mathrm{dw}^{-1} \mathrm{~h}^{-1}$ ) and lowest

Table 1. Ulva lactuca. Estimates of maximum uptake rate $V_{\max }$

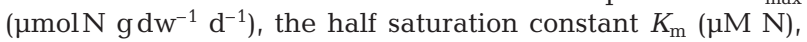
and the affinity for urea uptake at low concentrations ( $V_{\max } / K_{\mathrm{m}}$ Healy 1980 ) for surge uptake (0 to 2 min after exposure) and sustained uptake (20 to $30 \mathrm{~min}$ after exposure). The coefficient of determination $\left(\mathrm{r}^{2}\right)$ and standard error of the estimates are given. $\mathrm{N}=60$ for each phase of uptake

\begin{tabular}{|llccc|}
\hline & $V_{\max }$ & $K_{\mathrm{m}}$ & $V_{\max } / K_{\mathrm{m}}$ & $\mathrm{r}^{2}$ \\
\hline Surge & $68 \pm 19$ & $15 \pm 7$ & 4.5 & 0.53 \\
Sustained & $22 \pm 7$ & $19 \pm 9$ & 1.2 & 0.61 \\
\hline
\end{tabular}




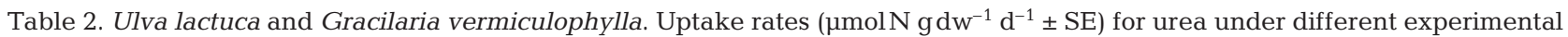
conditions. Prior light: light intensity during the acclimation period; experimental light: light intensity during exposure to urea; Nutrient: components present in solution. 'Initial' uptake was measured in the first 10 min of the experiment; 'Sustained' uptake was measured at several points between 10 and $150 \mathrm{~min} . \mathrm{n}=20$ for initial rates and $\mathrm{n}=80$ for sustained rates

\begin{tabular}{|llcccc|}
\hline \multirow{2}{*}{ Test } & Treatment & \multicolumn{2}{c|}{ Initial uptake rate } & \multicolumn{2}{c}{$\begin{array}{c}\text { Sustained uptake rate } \\
\text { U. lactuca }\end{array}$} \\
& & G. vermiculophylla & U. lactuca & G. vermiculophylla \\
\hline Prior light & Low & $12.2 \pm 0.9$ & $16.3 \pm 0.7$ & $2.3 \pm 0.1$ & $5.4 \pm 0.4$ \\
& High & $12.1 \pm 1.0$ & $17.0 \pm 0.7$ & $2.4 \pm 0.2$ & $4.8 \pm 0.2$ \\
Experimental light & Light & $11.0 \pm 0.9$ & $17.8 \pm 0.8$ & $2.5 \pm 0.2$ & $5.1 \pm 0.2$ \\
& Dark & $13.2 \pm 1.0$ & $15.6 \pm 0.5$ & $2.2 \pm 0.1$ & $5.1 \pm 0.2$ \\
Nutrient & Urea only & $11.6 \pm 0.9$ & $16.1 \pm 0.7$ & $2.3 \pm 0.1$ & $4.6 \pm 0.2$ \\
Overall mean & Urea $+\mathrm{NH}_{4}{ }^{+}$ & $12.7 \pm 1.0$ & $17.1 \pm 0.8$ & $2.4 \pm 0.2$ & $5.6 \pm 0.3$ \\
& & $12.2 \pm 0.7$ & $16.6 \pm 0.5$ & $2.3 \pm 0.1$ & $5.1 \pm 0.2$ \\
\hline
\end{tabular}
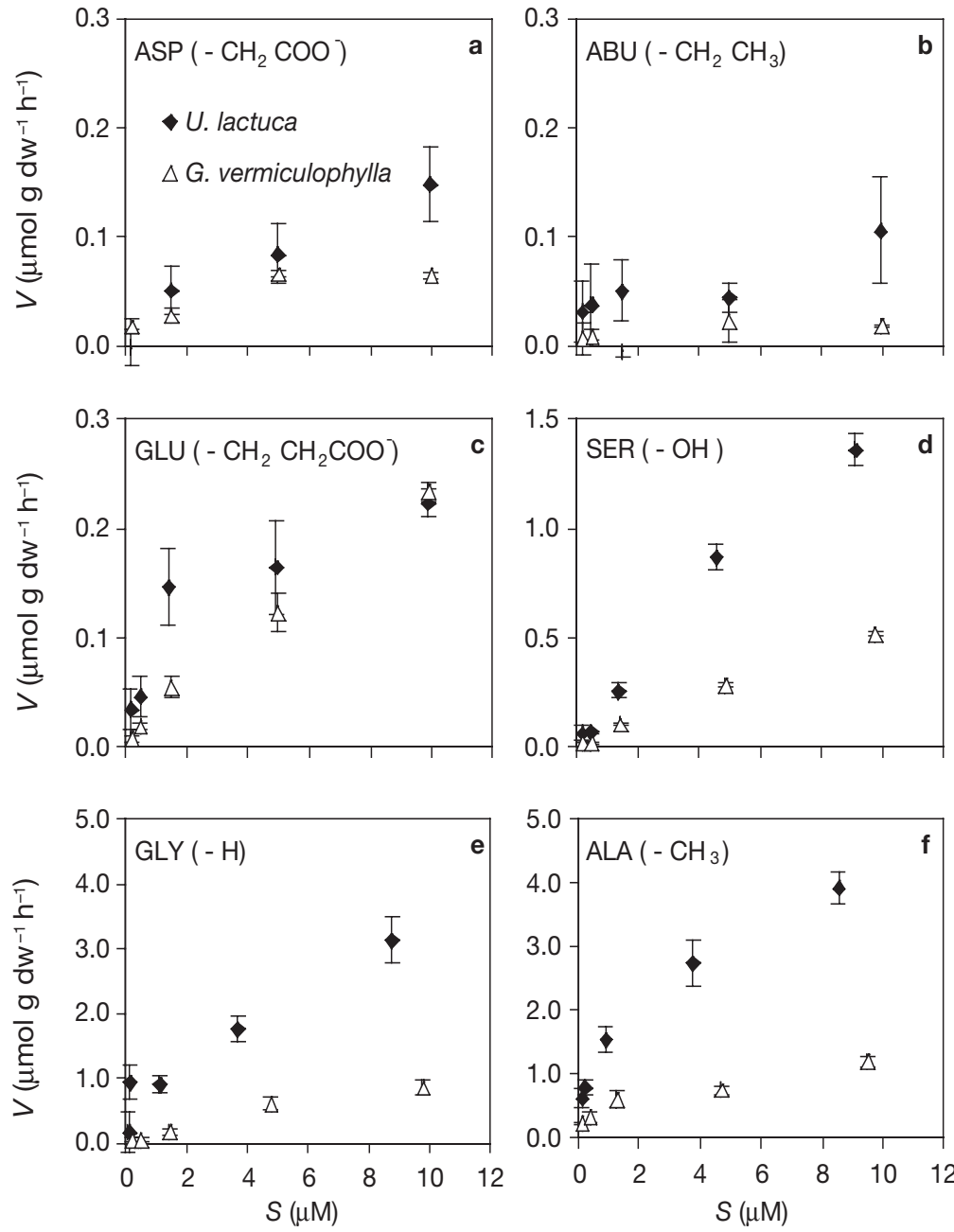

Fig. 3. Ulva lactuca and Gracilaria vermiculophylla. Amino acid uptake rates $(V)$ as a function of concentration $(S)$ for (a) aspartic acid, (b) aminobutyrate, (c) glutamic acid, (d) serine, (e) glycine and (f) alanine. The side chain of each amino acid is shown in parentheses. Estimates for the kinetic parameters maximum uptake rate $\left(V_{\max }\right)$ and half saturation constant $\left(K_{\mathrm{m}}\right)$ based on these figures are given in Table 3. Errors are the standard error of the mean for $\mathrm{n}=3$. Note the different scales on $y$-axes for ABU acid. The maximum observed uptake rates and the estimated affinities were consistently greatest for ALA for both species.

There was no observable effect of $\mathrm{NH}_{4}{ }^{+}$ on ALA uptake for either species (Table 4), and vice versa (data not shown). Both species had high surge uptake rates for $\mathrm{NH}_{4}{ }^{+}$, but not ALA. The estimated uptake rates of ALA and $\mathrm{NH}_{4}{ }^{+}$obtained for the 2 methods (Table 4 ) were consistent with one another $\left({ }^{15} \mathrm{~N}\right.$ estimate $=[0.86 \times$ disappearance estimate] +0.03 ) and highly significant $\left(\mathrm{r}^{2}=0.99, F=1191, \mathrm{p}<0.0001\right)$. However, the ${ }^{15} \mathrm{~N}$ method underestimated the uptake based on traditional disappearance methods by approximately $14 \%$.

The uptake rate of GLY was similar in the light and dark for both species (Fig. 4). The change in tissue ${ }^{15} \mathrm{~N}$ was relatively constant with respect to time for Gracilaria vermiculophylla over the $4 \mathrm{~h}$ period, but had a hyperbolic shape for Ulva lactuca. The uptake rate ( 1 to $1.6 \mu \mathrm{mol} \mathrm{g} \mathrm{dw}^{-1} \mathrm{~h}^{-1}$ ) for $G$. vermiculophylla also was relatively constant over the $4 \mathrm{~h}$ incubation, whereas the rate for $U$. lactuca was initially $3.3 \mu \mathrm{mol}$ $\mathrm{g} \mathrm{dw}^{-1} \mathrm{~h}^{-1}$ and leveled off to $1.4 \mu \mathrm{mol} \mathrm{g}$ $\mathrm{dw}^{-1} \mathrm{~h}^{-1}$ after $4 \mathrm{~h}$.

Nitrogen fertilization during the acclimation period had a significant effect on GLY and ALA uptake rates for Ulva lactuca, but not for Gracilaria vermiculophylla (Table 5). All rates for G. vermiculophylla were statistically similar, and lower than those measured for U. lactuca. GLY uptake by U. lactuca was significantly higher for low $\mathrm{N}$ and $\mathrm{NH}_{4}{ }^{+}$fertilized thalli than for $\mathrm{NO}_{3}{ }^{-}$fer- 
Table 3. Ulva lactuca and Gracilaria vermiculophylla. Kinetic uptake parameters for 6 different amino acids. Maximum uptake rate $V_{\max }(\mu \mathrm{mol} \mathrm{N} \mathrm{g}$ $\left.\mathrm{dw}^{-1} \mathrm{~d}^{-1}\right)$ and half saturation constant $K_{\mathrm{m}}(\mu \mathrm{M} \mathrm{N})$ were estimated from uptake data shown in Fig. 3 using least squares regression. Coefficient of determination $\left(\mathrm{r}^{2}\right)$ and $\mathrm{SE}$ of the estimates are given. The affinity for amino acid uptake at low concentrations $\left(V_{\max } / K_{\mathrm{m}}\right.$ Healy 1980) and the measured maximum uptake rate (starting concentration $\sim 10 \mu \mathrm{M}$ amino acid $\mathrm{N}, \mathrm{n}=3$, error is standard error of the mean) are also given. In some cases, where uptake rates were very low, the kinetic uptake parameters could not be reliably estimated and are not included. Amino acid abbreviations are as follows: aspartic acid: ASP; aminobutyrate: ABU; glutamic acid: GLU; serine: SER; glycine: GLY; alanine: ALA

\begin{tabular}{|c|c|c|c|c|c|}
\hline & $V_{\max }$ & $K_{\mathrm{m}}$ & $V_{\max } / K_{\mathrm{m}}$ & $r^{2}$ & $V_{\max }$ measured \\
\hline \multicolumn{6}{|c|}{ U. lactuca } \\
\hline ASP & $0.37 \pm 0.15$ & $0.83 \pm 0.57$ & 0.4 & 0.90 & $0.15 \pm 0.03$ \\
\hline $\mathrm{ABU}$ & - & - & - & - & $0.11 \pm 0.05$ \\
\hline GLU & $0.24 \pm 0.03$ & $0.10 \pm 0.05$ & 2.3 & 0.71 & $0.22 \pm 0.01$ \\
\hline SER & $3.90 \pm 0.99$ & $1.34 \pm 0.49$ & 2.9 & 0.98 & $1.36 \pm 0.07$ \\
\hline GLY & $5.69 \pm 2.53$ & $0.60 \pm 0.49$ & 9.5 & 0.74 & $3.14 \pm 0.37$ \\
\hline ALA & $4.80 \pm 0.84$ & $0.18 \pm 0.10$ & 26.4 & 0.82 & $3.92 \pm 0.26$ \\
\hline \multicolumn{6}{|c|}{ G. vermiculophylla } \\
\hline ASP & - & - & - & - & $0.06 \pm 0.00$ \\
\hline $\mathrm{ABU}$ & - & - & - & - & $0.02 \pm 0.00$ \\
\hline GLU & - & - & - & - & $0.23 \pm 0.01$ \\
\hline SER & $2.38 \pm 0.61$ & $2.83 \pm 0.90$ & 0.8 & 0.99 & $0.52 \pm 0.01$ \\
\hline GLY & $1.79 \pm 0.74$ & $0.82 \pm 0.56$ & 2.2 & 0.89 & $0.85 \pm 0.11$ \\
\hline ALA & $1.15 \pm 0.13$ & $0.07 \pm 0.03$ & 15.9 & 0.76 & $1.19 \pm 0.08$ \\
\hline
\end{tabular}

not significant for ALA uptake for either species (Fig. 5b). For the simultaneous uptake of ${ }^{15} \mathrm{~N}$ and ${ }^{13} \mathrm{C}_{1}$ we would expect a ratio of ${ }^{13} \mathrm{C}:{ }^{15} \mathrm{~N}$ of 0.53 and 0.40 for GLY and ALA, respectively. The observed ratio for both amino acids and both species was approximately 0.1 and was not significant.

\section{DISCUSSION}

The experiments presented here demonstrate that small, labile organic nitrogen compounds have the potential to contribute significantly to the overall $\mathrm{N}$ demand of estuarine macroalgae. Indeed, as we have shown previously, urea and amino acids can constitute up to $90 \%$ of total macroalgal $\mathrm{N}$ uptake when water column DIN availability is low (Tyler et al. 2003). Thus, organic N may contribute substantially to macroalgal $\mathrm{N}$ demand, even when present at very low water concentrations. The cur- tilized thalli. In contrast, ALA uptake by low $\mathrm{N} U$. lactuca was significantly greater than for either the $\mathrm{NH}_{4}{ }^{+}$ or $\mathrm{NO}_{3}^{-}$fertilization treatments, which were similar.

The simultaneous uptake of ${ }^{15} \mathrm{~N}$ and ${ }^{13} \mathrm{C}_{2}$ should yield a tissue ratio of ${ }^{13} \mathrm{C}:{ }^{15} \mathrm{~N}$ of 0.52 and 0.37 for GLY and ALA, respectively, based on the initial atom $\%{ }^{15} \mathrm{~N}$ and ${ }^{13} \mathrm{C}$ of the solution. This ratio was 0.62 and was significant for GLY uptake by Ulva lactuca $\left(\mathrm{r}^{2}=0.41, F=5.6, \mathrm{p}=0.04\right.$; Fig. 5a); it was

Table 4. Ulva lactuca and Gracilaria vermiculophylla. Comparison between ${ }^{15} \mathrm{~N}$ uptake method and the traditional disappearance from solution method for uptake of ${ }^{15}$ ALA (alanine) only, ${ }^{15} \mathrm{ALA}$ in the presence of ${ }^{14} \mathrm{NH}_{4}{ }^{+}$and ${ }^{15} \mathrm{NH}_{4}{ }^{+}$only. Initial concentrations were 5 and $15 \mu \mathrm{M}$ of ALA and $\mathrm{NH}_{4}{ }^{+}$, respectively. Estimates are the mean $\mu \mathrm{mol} \mathrm{gdw}^{-1} \mathrm{~h}^{-1}$ and standard error for $\mathrm{n}=3$

\begin{tabular}{|c|c|c|}
\hline & $\begin{array}{l}{ }^{15} \mathrm{~N} \\
\text { method }\end{array}$ & $\begin{array}{c}\text { Disappearance } \\
\text { method }\end{array}$ \\
\hline \multicolumn{3}{|l|}{ U. lactuca } \\
\hline${ }^{15}$ ALA (only) & $2.5 \pm 0.4$ & $2.8 \pm 0.4$ \\
\hline${ }^{15} \mathrm{ALA}\left(+{ }^{14} \mathrm{NH}_{4}{ }^{+}\right)$ & $2.6 \pm 0.2$ & $2.8 \pm 0.1$ \\
\hline${ }^{14} \mathrm{NH}_{4}{ }^{+}\left(+{ }^{15} \mathrm{ALA}\right)$ & - & $10.9 \pm 0.8$ \\
\hline${ }^{15} \mathrm{NH}_{4}^{+}$(only) & $9.2 \pm 0.5$ & $10.3 \pm 0.7$ \\
\hline \multicolumn{3}{|l|}{ G. vermiculophylla } \\
\hline${ }^{15}$ ALA (only) & $0.6 \pm 0.0$ & $0.8 \pm 0.1$ \\
\hline${ }^{15} \mathrm{ALA}\left(+{ }^{14} \mathrm{NH}_{4}{ }^{+}\right)$ & $0.7 \pm 0.1$ & $0.8 \pm 0.2$ \\
\hline${ }^{14} \mathrm{NH}_{4}{ }^{+}\left(+{ }^{15} \mathrm{ALA}\right)$ & - & $7.1 \pm 1.0$ \\
\hline${ }^{15} \mathrm{NH}_{4}{ }^{+}$(only) & $6.0 \pm 0.4$ & $7.3 \pm 0.5$ \\
\hline
\end{tabular}
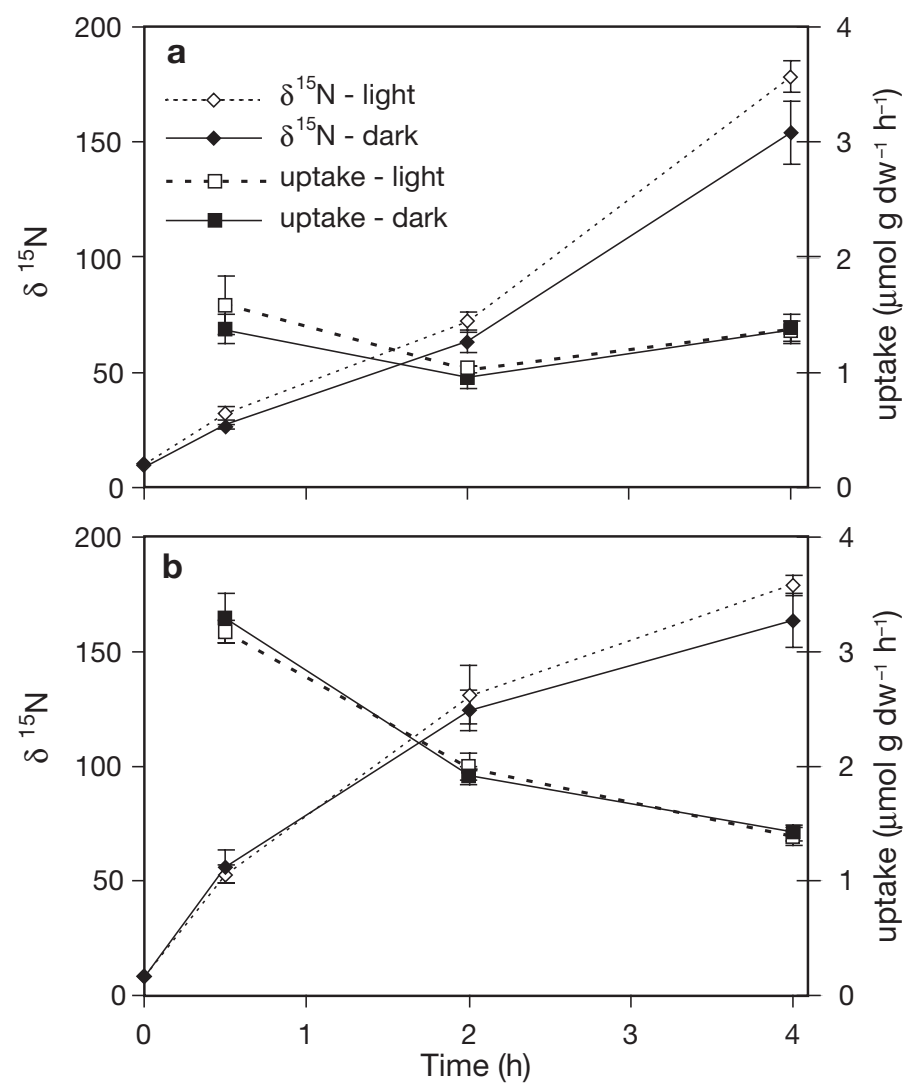

Fig. 4. Gracilaria vermiculophylla and Ulva lactuca. Change in tissue $\delta^{15} \mathrm{~N}$ and uptake rates of glycine $(\mathrm{GLY}, \pm \mathrm{SE}$ ) over a $4 \mathrm{~h}$ incubation for (a) G. vermiculophylla and (b) U. lactuca 
Table 5. Ulva lactuca and Gracilaria vermiculophylla. Uptake rates ( $\mu \mathrm{molN} \mathrm{g} \mathrm{dw}{ }^{-1} \mathrm{~h}^{-1}$ ) for GLY (glycine) and ALA (alanine) under different conditions of prior $\mathrm{N}$ fertilization $(\mathrm{n}=3)$. Treatments are: low $\mathrm{N}=$ no prior fertilization, $\mathrm{NH}_{4}{ }^{+}=$prior fertilization with $\mathrm{NH}_{4}{ }^{+}, \mathrm{NO}_{3}{ }^{-}=$prior fertilization with $\mathrm{NO}_{3}{ }^{-}$. Significant differences between treatments for each combination of amino acid and species are noted by different superscripted letters; values with the same letter are not different from each other based on 1-way ANOVA

\begin{tabular}{|c|c|c|c|c|}
\hline & Low N & $\mathrm{NH}_{4}^{+}$ & $\mathrm{NO}_{3}^{-}$ & $\mathrm{p}$ \\
\hline \multicolumn{5}{|c|}{ U. lactuca } \\
\hline GLY & $1.75 \pm 0.20^{\mathrm{a}}$ & $1.87 \pm 0.30^{\mathrm{a}}$ & $0.36 \pm 0.22^{\mathrm{b}}$ & 0.016 \\
\hline ALA & $2.74 \pm 0.36^{\mathrm{a}}$ & $0.64 \pm 0.17^{b}$ & $0.28 \pm 0.11^{b}$ & 0.002 \\
\hline \multicolumn{5}{|c|}{ G. vermiculophylla } \\
\hline GLY & $0.62 \pm 0.11^{\mathrm{a}}$ & $0.66 \pm 0.24^{\mathrm{a}}$ & $0.59 \pm 0.05^{\mathrm{a}}$ & 0.950 \\
\hline ALA & $0.75 \pm 0.07^{\mathrm{a}}$ & $0.22 \pm 0.18^{a}$ & $0.54 \pm 0.02^{\mathrm{a}}$ & 0.088 \\
\hline
\end{tabular}

rent study also shows that the uptake rates and kinetic uptake parameters measured vary substantially among compounds, suggesting different uptake mechanisms for urea and amino acids and for the different amino acids studied.
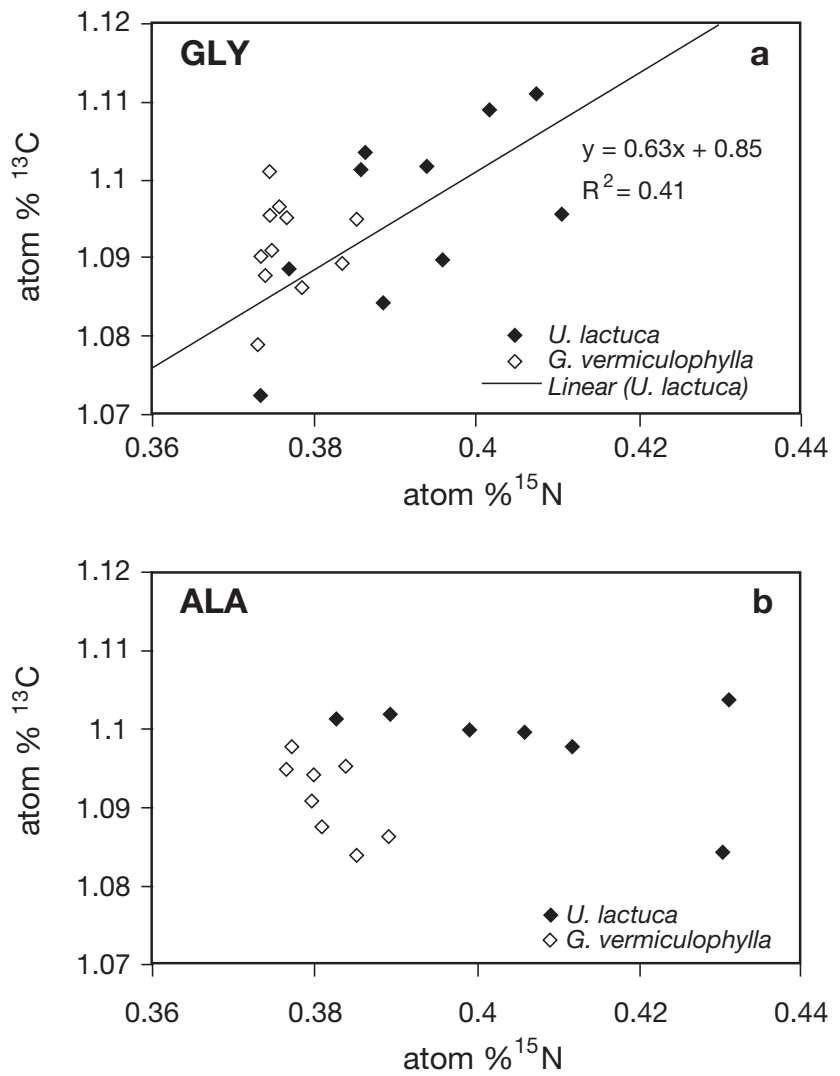

Fig. 5. Ulva lactuca and Gracilaria vermiculophylla. Comparison between change in atom $\%{ }^{15} \mathrm{~N}$ and ${ }^{13} \mathrm{C}_{2}$ for uptake of (a) glycine and (b) alanine. The least-squares regression line is shown for glycine uptake by $U$. lactuca and was the only significant relationship between ${ }^{15} \mathrm{~N}$ and ${ }^{13} \mathrm{C}_{2}$ assimilation; the resulting equation and coefficient of determination are shown in (a)

\section{Urea uptake}

Ulva lactuca and Gracilaria vermiculophylla both had 2 distinct phases for urea uptake: a very rapid initial uptake phase and a much lower sustained, or assimilation phase. A similar phenomenon has been shown for $\mathrm{NH}_{4}{ }^{+}$ uptake by several macroalgae (e.g. Fujita 1985, Harrison et al. 1989, McGlathery et al. 1996, Pedersen \& Borum 1997) and for urea by the brown macroalgae Chordaria flagelliformis (Probyn \& Chapman 1982). The change in rates during prolonged exposure may be due to the rapid filling of internal pools, after which uptake proceeds more slowly due to feedback inhibition (Fujita et al. 1988, Harrison et al. 1989). Our estimate of $V_{\text {max }}$ during the surge uptake phase by U. lactuca (65 to $76 \mu \mathrm{mol} \mathrm{g} \mathrm{dw}^{-1} \mathrm{~h}^{-1}$ ) is similar to that measured for $C$. flagelliformis $\left(V_{\max }=51\right.$ to $66 \mathrm{mmol} \mathrm{g} \mathrm{dw} \mathrm{h}^{-1}$ Probyn \& Chapman 1982). The uptake by $U$. lactuca during the

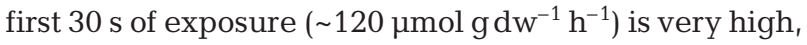
suggesting an ability to rapidly consume pulses of urea. The lower surge uptake rate measured for G. vermiculophylla suggests that $U$. lactuca may be better adapted to conditions of pulsed $\mathrm{N}$ availability. Overall, the results of the short term experiment indicate that the intracellular urea pools of both species fill within 15 min of exposure to urea, and that sustained uptake rates can be satisfactorily estimated after this initial period. The lower sustained assimilation rates show a similar relative difference between species in all experiments (Table 2). The sustained $V_{\max }$ for $C$. flagelliformis (13 $\mu \mathrm{mol} \mathrm{g} \mathrm{dw} \mathrm{h}^{-1} \mathrm{~h}^{-1}$ Probyn \& Chapman 1982) is similar to what we measured for $U$. lactuca $(22 \pm 7 \mu \mathrm{mol}$ $\mathrm{g} \mathrm{dw}^{-1} \mathrm{~h}^{-1}$ ); these species may have an advantage relative to a species such as G. vermiculophylla when urea is an important part of the $\mathrm{N}$ pool.

Uptake of urea by Ulva lactuca exhibited saturatable uptake kinetics (Fig. 2), which indicates either facilitated diffusion of urea across the cell membrane or an active, energy-demanding transport process (Lobban \& Harrison 1997, p. 171-172). The higher uptake observed in the light compared to the dark (Fig. 2) also suggests an uptake mechanism that requires ATP. Lower urea uptake rates in the darkness were also measured in long-term experiments with Chordaria flagelliformis (Probyn \& Chapman 1982) and the matforming cyanobacteria Lyngbya gracialis (Rondell et al. 2000), suggesting continuity in uptake mechanisms among species and functional groups.

Greater uptake of urea in the presence of $\mathrm{NH}_{4}{ }^{+}$by Ulva lactuca suggests that the uptake mechanisms for these 2 molecules are distinct and that the presence of one does not inhibit uptake of the other. The $K_{\mathrm{m}}$ values for urea uptake by $U$. lactuca fall within the same range of $K_{\mathrm{m}}$ values measured for $\mathrm{NH}_{4}^{+}$uptake by Pedersen \& Borum 1997 (6 to $21 \mathrm{mM}$ ), but are less than 
that reported by Fujita (1985). Our values are also consistent with Chordaria flagelliformis, which had a similar $K_{\mathrm{m}}$ for urea and $\mathrm{NH}_{4}^{+}$(Probyn \& Chapman 1982). The similarity between the $K_{\mathrm{m}}$ values suggests that the affinity for the carrier sites is similar between urea and $\mathrm{NH}_{4}{ }^{+}$. However, it has been suggested that $V_{\text {max }} / K_{\mathrm{m}}$ may be a better indicator of the affinity for an ion, because the value of $K_{\mathrm{m}}$ is dependent upon $V_{\text {max }}$ (Healy 1980, Harrison et al. 1989). The affinity of $U$. lactuca for urea at low concentrations $\left(V_{\max } / K_{\mathrm{m}}=4.5\right)$ was low relative to the affinity of $U$. lactuca for $\mathrm{NH}_{4}{ }^{+}$ ( 12; Pedersen \& Borum 1997), but similar to the affinity for nitrate ( 4.5; Pedersen \& Borum 1997). Thus, when all 3 compounds are in equally low supply, urea and $\mathrm{NO}_{3}{ }^{-}$are less desirable $\mathrm{N}$ sources than $\mathrm{NH}_{4}{ }^{+}$. One potential explanation for this discrepancy is that $\mathrm{NO}_{3}{ }^{-}$ and urea require alteration, via nitrate reductase and urease, respectively, within the cell prior to incorporation into amino acids, whereas $\mathrm{NH}_{4}{ }^{+}$can be directly incorporated. From this, we may infer that uptake of urea is more energy-demanding than $\mathrm{NH}_{4}{ }^{+}$such that active urea uptake is induced only upon exposure to higher concentrations in the water column.

\section{Amino acid uptake}

The 2 methods that we used to measure amino acid uptake agree quite well at both low (Gracilaria vermiculophylla) and high (Ulva lactuca) rates of ALA uptake. The lower uptake rate estimated by ${ }^{15} \mathrm{~N}$ assimilation (by $14 \%$ ) is consistent with studies suggesting that uptake measured by ${ }^{15} \mathrm{~N}$ assimilation routinely underestimates the actual $\mathrm{N}$ uptake because of the potential for rapid turnover and release of $N$ (e.g. Williams \& Fisher 1985, Naldi \& Wheeler 2002). We utilized a short incubation time in the present study to eliminate potential release of the ${ }^{15} \mathrm{~N}$ label, so this likely accounts for only a small percentage of our underestimate. Schmitz \& Riffarth (1979), in a study of ${ }^{14} \mathrm{C}$ labeled L-leucine uptake by the brown algae Giffordia mitchellae, demonstrated that repeated rinsing of macroalgal tissue after exposure to L-leucine resulted in the release of $13 \%$ of the ${ }^{14} \mathrm{C}$ originally removed from solution. They presumed that this release was L-leucine incorporated into the apoplast, but not yet assimilated into the cell proper. In the present study, a similar loss may have occurred during the rinsing of macroalgal thalli following removal from the incubation solution. This would result in a loss of the ${ }^{15} \mathrm{~N}$ label from the tissue and hence a lower estimate of ${ }^{15} \mathrm{~N}$ assimilation. Because of the potential for loss of the ${ }^{15} \mathrm{~N}$ label during rinsing and through leakage back into solution, we caution that the rates reported here based on ${ }^{15} \mathrm{~N}$ and ${ }^{13} \mathrm{C}$ uptake represent assimilation rates, rather than total uptake.
In general, macroalgal uptake rates for aliphatic neutral amino acids were highest and acidic amino acids were lowest, although this trend doesn't hold across all amino acids measured. This suggests that the potential for uptake is not necessarily proportional to the relative concentration of these amino acids in the environment and that even among chemically similar molecules the uptake mechanism varies. Consistent with the observed pattern of urea uptake, amino acid uptake by Ulva lactuca was greater than Gracilaria vermiculophylla for all amino acids. The kinetic uptake parameters for L-leucine estimated by Schmitz \& Riffarth (1979) for the brown algae Giffordia mitchellae were relatively high $\left(V_{\max }=30\right.$ to $38 \mu \mathrm{mol} \mathrm{g} \mathrm{dw}{ }^{-1} \mathrm{~h}^{-1}$, $K_{\mathrm{m}}=3$ to $\left.14 \mu \mathrm{M}\right)$; however, these rates were measured at very high ( $1 \mathrm{mM}$ amino acid-N) concentrations and may never be realized at the low concentrations found under field conditions. As such, the authors suggest that a more realistic estimate of total amino acid uptake in the field is $0.3 \mu \mathrm{mol} \mathrm{g} \mathrm{dw}^{-1} \mathrm{~h}^{-1}$, which is in the range of values that we measured for other amino acids in this study.

In a previous study, we measured uptake of sediment-derived DFAA by Ulva lactuca in Hog Island Bay (Tyler et al. 2003). In these experiments, we observed the highest uptake rates for GLY (124 nmolN $\mathrm{g} \mathrm{dw}^{-1}$ $\mathrm{d}^{-1}$ ), SER (89 nmolN $\left.\mathrm{gdw}^{-1} \mathrm{~d}^{-1}\right)$, ARG (62 nmolN $\mathrm{gdw}^{-1} \mathrm{~d}^{-1}$ ) and ALA (36 nmolN g dw ${ }^{-1} \mathrm{~d}^{-1}$ ); uptake of GLU (9 nmolN gdw $\left.{ }^{-1} d^{-1}\right)$, ABU (13 nmolN gdw $\left.{ }^{-1} d^{-1}\right)$ and ASP (21 nmolN g dw $\mathrm{d}^{-1}$ ) were substantially lower, in spite of small differences in the relative concentration between amino acids (Tyler et al. 2003). In particular, GLY and SER were preferentially taken up, at rates somewhat higher than their relative concentration in the water column. With the exception of ALA, the results from direct uptake experiments agree well with the previous study, which may be attributable to the low concentration of ALA in Hog Island Bay.

Surge uptake was absent for ALA, which suggests that the mechanism of uptake, although saturatable and thereby energy-demanding, differs from that for urea and $\mathrm{NH}_{4}{ }^{+}$. However, the uptake mechanism for ALA also seems to differ from that for GLY, making it difficult to generalize across amino acids. The low ratio of ${ }^{13} \mathrm{C}_{1}:{ }^{15} \mathrm{~N}$ incorporation suggests that the $\mathrm{C}_{1}$ carbon was not assimilated and that both ALA and GLY were decarboxylated prior to uptake by the 2 species. However, the consistency between predicted and observed ${ }^{13} \mathrm{C}_{2}:{ }^{15} \mathrm{~N}$ uptake ratios indicates that the remainder of the GLY molecule was assimilated intact by Ulva lactuca (Fig. 5). ALA, on the other hand, appeared to be deaminated prior to uptake; only the amino group was assimilated. This is consistent with the results of Palenik \& Morel (1990a) who found that the cell surface amino acid oxidase enzyme of phytoplankton is 
selective for specific L-amino acids. Of the amino acids measured in this study, they report that ASP, GLU, ABU and ALA are active; GLY and SER are inactive (Palenik \& Morel 1990a). The high uptake rates of GLY and SER observed in current and previous studies (Tyler et al. 2003), and the lack of deamination observed for GLY suggests that the uptake mechanism may be similar among macroalgae and phytoplankton. The assimilation of the remainder of the molecule following decarboxylation may foster higher uptake rates relative to amino acids that must be deaminated prior to uptake. GLY uptake was similar in the light and dark, suggesting a less energy-costly uptake mechanism. If the mechanisms of GLY and ALA uptake are similar between Gracilaria vermiculophylla and $U$. lactuca, the lack of a relationship in G. vermiculophylla between $\mathrm{N}$ and $\mathrm{C}$ uptake may be due to the low overall uptake rate.

The variability in uptake rates of ALA and GLY for fertilized versus unfertilized macroalgae suggests further differences in the mechanisms of uptake. The low uptake rate of GLY by $\mathrm{NO}_{3}{ }^{-}$-fertilized compared to $\mathrm{N}$ - starved or $\mathrm{NH}_{4}{ }^{+}$-fertilized Ulva lactuca suggests that the GLY uptake mechanism was induced by both $\mathrm{N}$ starvation and $\mathrm{NH}_{4}{ }^{+}$fertilization, but not by $\mathrm{NO}_{3}{ }^{-}$ fertilization. U. lactuca may not discriminate between GLY and $\mathrm{NH}_{4}{ }^{+}$, so that the uptake of both occurs simultaneously. Uptake of amino acids is also inhibited by $\mathrm{NO}_{3}{ }^{-}$in certain species of benthic microalgae; however, the effect is variable among different amino acids (Admiraal et al. 1984). The mechanism for ALA uptake may be different from that for $\mathrm{NH}_{4}{ }^{+}$, so that there is discrimination between the 2 compounds. This may indicate that ALA uptake is induced only when DIN concentrations are low, and that fertilization with either $\mathrm{NO}_{3}{ }^{-}$or $\mathrm{NH}_{4}{ }^{+}$shuts off this potentially energydemanding process. Further, we found no inhibition of ALA uptake by $\mathrm{NH}_{4}{ }^{+}$, in contrast to reported $\mathrm{NH}_{4}{ }^{+}$ inhibition of uptake in phytoplankton (Palenik \& Morel 1990b), which suggests that when N-limited, U. lactuca is capable of simultaneous uptake of both amino acids and $\mathrm{NH}_{4}{ }^{+}$. We have previously demonstrated that $U$. lactuca utilizes DON compounds when DIN in the water column is low (Tyler et al. 2003).

The $K_{\mathrm{m}}$ values for ALA uptake in both Ulva lactuca and Gracilaria vermiculophylla were similar to $K_{\mathrm{m}}$ values for phytoplankton (Palenik \& Morel 1990b), but much lower than those measured in this study for urea. Amino acid uptake therefore saturates at very low concentrations, and because of the low $K_{\mathrm{m}}$, the affinity of both macroalgal species for ALA at low concentrations was high. These results suggest that the amino acid uptake mechanism in macroalgae is specific for the low concentrations of amino acids commonly found in shallow, estuarine environments.

\section{Ecological significance}

The observed variation in uptake kinetics between $\mathrm{N}$-containing compounds suggests that there are distinctly different nutrient delivery mechanisms in the environment. Rapid uptake of nutrients and subsequent storage in macroalgal tissue allows for the temporal separation of nutrient uptake and growth, and may permit higher growth rates during periods of low nutrient availability (Fujita 1985). Both Ulva sp. and Gracilaria sp. are capable of storage of $\mathrm{N}$ in excess of growth demands (Ryther et al. 1981, Bird et al. 1982, Rosenberg \& Ramus 1982, Fujita 1985). However the tissue turnover in Ulva sp. is typically greater than in Gracilaria sp., which may allow Gracilaria sp. to persist for a longer time under low nutrient conditions (Rosenberg \& Ramus 1982, Fujita 1985). Both species exhibit similar surge uptake patterns for $\mathrm{NH}_{4}{ }^{+}$uptake (Fujita 1985), but $U$. lactuca has a distinct advantage over $G$. vermiculophylla if urea is an important component of the pulsed $\mathrm{N}$ input to the system. The lack of surge uptake for amino acids such as ALA suggests that the amino acid supply is not likely to come as pulses, but rather may be a low, but consistent supply based on organic matter turnover in the water column or sediments. This would be consistent with the very rapid turnover of amino acids in seawater (e.g. Tupas \& Koike 1990). The high affinity suggests that macroalgae, particularly $U$. lactuca, can take advantage of even very low concentrations of amino acids. The ability to utilize these compounds may provide a competitive advantage to those species capable of uptake under conditions of low N availability (Nilsson \& Sundback 1996).

In incubation experiments with sediments from Hog Island Bay, Virginia, uptake of both urea and amino acids by Ulva lactuca had a significant impact on both water column concentrations and fluxes between the sediment and the water column. Total free amino acid concentrations ranged from 0.02 to $0.43 \mu \mathrm{M}$ in Hog Island Bay and uptake from both sediment and water column sources was $0.43 \mu \mathrm{mol} \mathrm{N} \mathrm{gdw}{ }^{-1} \mathrm{~d}^{-1}$ (Tyler 2002). GLY, generally $\sim 14 \%$ of the water column free amino acid pool, had concentrations ranging from 3 to $60 \mathrm{nM}$. Based on the Michaelis-Menten parameters estimated here, at these concentrations the uptake rate by $U$. lactuca would be 0.03 to $0.52 \mu \mathrm{mol} \mathrm{g} \mathrm{dw}^{-1} \mathrm{~h}^{-1}$. Given that the mean macroalgal biomass in Hog Island Bay is $18.2 \mathrm{~g} \mathrm{dw} \mathrm{m}^{-2}$, with patches up to $1437.0 \mathrm{~g} \mathrm{dw}$ $\mathrm{m}^{-2}$ (Thomsen et al. unpubl. data), macroalgae have the potential to significantly impact water column amino acid concentrations. Likewise, the average concentration of urea in the waters of Hog Island Bay is low $(0.7 \mu \mathrm{M})$, with a range from 0.2 to $2.3 \mu \mathrm{M}$, and it constitutes only 2 to $10 \%$ of the standing stock total dissolved N pool (Tyler et al. 2001, 2003). Given the 
kinetic uptake parameters measured for U. lactuca in the present study, this would result in potential sustained uptake rates between 0.3 and $2.7 \mu \mathrm{mol} \mathrm{g} \mathrm{dw}^{-1}$ $\mathrm{h}^{-1}$. In addition, fluxes of urea from the sediments can at times be substantially greater than the concurrent dissolved inorganic nitrogen flux (range $=-184$ to $1327 \mu \mathrm{mol} \mathrm{m} \mathrm{m}^{-1}$; Tyler et al. 2003). We found that, when present at significantly high densities, macroalgae are capable of intercepting all urea released from the sediments. This is particularly true because of the capacity for very rapid uptake of transient urea pulses by both U. lactuca and Gracilaria vermiculophylla.

Overall, the importance of organic nitrogen to macroalgal $\mathrm{N}$ nutrition depends on the availability of both dissolved inorganic and organic nitrogen compounds. We have previously demonstrated that where the inorganic $\mathrm{N}$ supply in the water column or released from the sediments was high, amino acids and urea were a relatively small fraction of $\mathrm{N}$ assimilated by the macroalgae (2 to 3 and 10 to $20 \%$, respectively; Tyler et al. 2003). Yet, when dissolved inorganic nitrogen was low, either routinely or seasonally, total $\mathrm{N}$ uptake was also low, and both compounds played a much more important role (20 and $40 \%$, respectively Tyler et al. 2003). This suggests that the importance of urea and DFAA is dependent only on the local availability relative to $\mathrm{NH}_{4}{ }^{+}$, the major inorganic nitrogen component of both the water column and sediment effluxes in Hog Island Bay.

Acknowledgements. We are grateful to T. Mastronicola, J. Spitler, L. Skane, J. Burton and J. Maben for their assistance with field and laboratory work, and to J. Galloway for the use of his HPLC system. This material is based upon work supported by the National Science Foundation under Grant Nos. DEB-9411974 (Virginia Coast Reserve LTER) and DEB9805928 (to K.J.M.), the U.S. Environmental Protection Agency under Grant No. U-915532 (STAR Graduate Fellowship to A.C.T.) and the Phycological Society of America (Grant-in-Aid to A.C.T.).

\section{LITERATURE CITED}

Admiraal W, Peletier H (1979) Influence of organic compounds and light limitation on the growth rate of estuarine benthic diatoms. Br Phycol J 14:197-206

Admiraal W, Laane RWP, Peletier H (1984) Participation of diatoms in the amino acid cycle of coastal water; uptake and excretion in cultures. Mar Ecol Prog Ser 15:303-306

Antia NJ, Harrison PJ, Oliveira L (1991) The role of dissolved organic nitrogen in phytoplankton nutrition, cell biology and ecology. Phycologia 30:1-89

Berg GM, Glibert PM, Lomas MW, Burford MA (1997) Organic nitrogen uptake and growth by the chrysophyte Aureococcus anophagefferens during a brown tide event. Mar Biol 129:377-387

Bird KT, Habig C, DeBusk T (1982) Nitrogen allocation and storage patterns in Gracilaria tikvahiae (rhodophyta). J Phycol 18:344-348
Boucher G, Boucher-Rodoni R (1988) In situ measurement of respiratory metabolism and nitrogen fluxes at the interface of oyster beds. Mar Ecol Prog Ser 44:229-238

Bronk DA, Glibert PM (1993) Application of a ${ }^{15} \mathrm{~N}$ tracer method to the study of dissolved organic nitrogen uptake during spring and summer in Chesapeake Bay. Mar Biol 115:501-508

Chapin FS III, Moilanen L, Kielland K (1993) Preferential use of organic nitrogen for growth by a non-mycorrhizal arctic sedge. Nature 361:150-153

Chisholm JRM, Duaga C, Ageron E, Grimont PAD, Jaubert JM (1996) 'Roots' in mixotrophic algae. Nature 381:382

Cho BC, Park MG, Shim JH, Azam F (1996) Significance of bacteria in urea dynamics in coastal surface waters. Mar Ecol Prog Ser 142:19-26

Flynn KJ, Butler I (1986) Nitrogen sources for the growth of marine microalgae: role of dissolved free amino acids. Mar Ecol Prog Ser 34:281-304

Fujita RM (1985) The role of nitrogen status in regulating transient ammonium uptake and nitrogen storage by macroalgae. J Exp Mar Biol Ecol 92:283-301

Fujita RM, Wheeler PA, Edwards RL (1988) Metabolic regulation of ammonium uptake by Ulva rigida (Chlorophyta): a compartmental analysis of the rate-limiting step for uptake. J Phycol 24:560-566

Glibert PM, Magnien R, Lomas MW, Alexander J, Fan CK, Haramoto E, Trice M, Kana TM (2001) Harmful algal blooms in the Chesapeake and coastal bays of Maryland, USA: comparison of 1997, 1998, and 1999 events. Estuaries 24:875-883

Goeyens L, Kindermans N, Yusuf MA, Elskens M (1998) A room temperature procedure for the manual determination of urea in seawater. Estuar Coast Shelf Sci 47:415-418

Gurgel CFD, Fredericq S (2004) Systematics of the Graciliariaceae (Gracilariales, Rhodophyta): a critical assessment based on rbcL sequence analyses. J Phycol 40:138-59

Harrison PJ, Parlow JS, Conway HL (1989) Determination of nutrient uptake kinetic parameters: a comparison of methods. Mar Ecol Prog Ser 52:301-312

Healy FP (1980) Slope of the Monod equation as an indicator of advantage in nutrient competition. Microb Ecol 5: 281-286

Howarth RW (1988) Nutrient limitation of net primary production in marine ecosystems. Annu Rev Ecol Syst 19:89-110

Humm HJ (1979) The marine algae of Virginia. The University Press of Virginia, Charlottesville, VA

Jones BN, Paabo S, Stein S (1981) Amino acid analysis and enzymatic sequence determination of peptides by an improved o-phthaldialdehyde precolumn labeling procedure. J Liq Chromatogr 4:565-586

Lobban CS, Harrison PJ (1997) Seaweed ecology and physiology. Cambridge University Press, New York

Lomas MW, Glibert PM, Berg GM, Burford M (1996) Characterization of nitrogen uptake by natural populations of Aureococcus anophagefferens (Chrysophyceae) as a function of incubation duration, substrate concentration, light, and temperature. J Phycol 32:907-916

Lomstein BA, Blackburn TH, Henriksen K (1989) Aspects of nitrogen and carbon cycing in the northern Bering Shelf sediment. I. The significance of urea turnover in the mineralization of $\mathrm{NH}_{4}^{+}$. Mar Ecol Prog Ser 57:237-247

Lomstein BA, Jensen A-GU, Hansen JW, Andreasen JB, Hansen LS, Berntsen J, Kunzendorf H (1998) Budgets of sediment nitrogen and carbon cycling in the shallow water of Knebel Vig, Denmark. Aquat Microb Ecol 14:69-80

Macko SA, Green EJ (1982) An investigation of the dissolved free amino acids and their relation to phytoplankton cell 
density in the Damariscotta River estuary, Maine. Estuaries 5:68-73

McGlathery KJ, Pedersen MF, Borum J (1996) Changes in intracellular nitrogen pools and feedback controls on nitrogen uptake in Chaetomorpha linum (Chlorophyta). J Phycol 32:393-401

Mulholland MR, Glibert PM, Berg GM, van Heukelem L, Pantoja S, Lee C (1998) Extracellular amino acid oxidation by microplankton: a cross-ecosystem comparison. Aquat Microb Ecol 15:141-152

Mulvenna PF, Savidge G (1992) A modified manual method for the determination of urea in seawater using diacetylmonoxime reagent. Estuar Coast Shelf Sci 34:429-438

Naldi M, Wheeler P (2002) N-15 measurements of ammonium and nitrate uptake by Ulva fenestrata (chlorophyta) and Gracilaria pacifica (rhodophyta): comparison of net nutrient disappearance, release of ammonium and nitrate, and N-15 accumulation in algal tissue. J Phycol 38: 135-144

Nasholm T, Ekblad A, Nordin A, Giesler R, Hogberg M, Hogberg P (1998) Boreal forest plants take up organic nitrogen. Nature 392

Navarro-Angulo L, Robledo D (1999) Effects of nitrogen source, N:P ratio and N-pulse concentration and frequency on the growth of Gracilaria cornea (Gracilariales, Rhodophyta) in culture. Hydrobiol 399:315-320

Nilsson C, Sundback K (1996) Amino acid uptake in natural microphytobenthic assemblages studied by microautoradiography. Hydrobiol 332:119-129

Palenik B, Morel FMM (1990a) Amino acid utilization by marine phytoplankton: a novel mechanism. Limnol Oceanogr 35:260-269

Palenik B, Morel FMM (1990b) Comparison of cell-surface Lamino acid oxidases from several marine phytoplankton. Mar Ecol Prog Ser 59:195-201

Pantoja S, Lee C (1994) Cell-surface oxidation of amino-acids in seawater. Limnol Oceanogr 39:1718-1726

Pedersen MF, Borum J (1997) Nutrient control of estuarine macroalgae: growth strategy and the balance between nitrogen requirements and uptake. Mar Ecol Prog Ser 161: 155-163

Probyn TA, Chapman ARO (1982) Nitrogen uptake characteristics of Chordaria flagelliformis (Phaeophyta) in batch mode and continuous mode experiments. Mar Biol 71: 129-133

Rondell JB, Finster KW, Lomstein BA (2000) Urea and DON uptake by a Lyngbya gracialis dominated microbial mat: a controlled laboratory experiment. Aquat Microb Ecol 21: 169-175

Rosenberg G, Ramus J (1982) Ecological growth strategies in

Editorial responsibility: Otto Kinne (Editor-in-Chief), Oldendorf/Luhe, Germany the seaweeds Gracilaria foliifera (Rhodophyceae) and Ulva Sp. (Chlorophyceae): soluble nitrogen and reserve carbohydrates. Mar Biol 66:251-259

Rueness J (2005) Life history and molecular sequences of Gracilaria vermiculophylla (Gracilariales, Rhodophyta), a new introduction to European waters. Phycologia 44:120-128

Ryther JH, Corwin N, DeBusk TA, Williams LD (1981) Nitrogen uptake and storage by the red alga Gracilaria tikvahiae (McLachlan, 1979). Aquaculture 26:107-115

Sand-Jensen K, Borum J (1991) Interactions among phytoplankton, periphyton, and macrophytes in temperate freshwater and estuaries. Aquat Bot 41:137-175

Schmitz K, Riffarth W (1979) Carrier-mediated uptake of L-leucine by the brown alga Giffordia mitchellae. Z Pflanzenphysiol 96:311-324

Sharp JH (1983) The distributions of inorganic nitrogen and dissolved and particulate organic nitrogen in the sea. In: Carpenter EJ,Capone DG (eds) Nitrogen in the marine environment. Academic Press, New York, p 1-35

Smith SV (1981) Marine macrophytes as a global carbon sink. Science 211:838-840

Solorzano L (1969) Determination of ammonia in natural waters by the phenolhypochlorite method. Limnol Oceanogr 14:799-801

Thomas TE, Harrison PJ, Taylor EB (1985) Nitrogen uptake and growth of the germlings and mature thalli of Fucus distichus. Mar Biol 84:267-274

Tupas L, Koike I (1990) Amino acid and ammonium utilization by heterotrophic marine bacteria grown in enriched seawater. Limnol Oceanogr 35:1145-1155

Turnbull MH, Schmidt S, Erskine PD, Richards S, Stewart GR (1996) Root adaptation and nitrogen source acquisition in natural ecosystems. Tree Physiol 16:941-948

Tyler AC (2002) Impact of benthic algae on dissolved organic nitrogen in a temperate, coastal lagoon. $\mathrm{PhD}$ thesis, University of Virginia, Charlottesville, VA

Tyler AC, McGlathery KJ, Anderson IC (2001) Macroalgal mediation of dissolved organic nitrogen fluxes in a temperate coastal lagoon. Estuar Coast Shelf Sci 53:155-168

Tyler AC, McGlathery KJ, Anderson IC (2003) Benthic algae control fluxes of dissolved organic and inorganic nitrogen compounds in a temperate, coastal lagoon. Limnol Oceanogr 48:2125-2137

Valiela I, McClelland J, Hauxwell J, Behr PJ, Hersh D, Foreman K (1997) Macroalgal blooms in shallow estuaries: controls and ecophysiological and ecosystem consequences. Limnol Oceanogr 42:1105-1118

Williams SL, Fisher TR (1985) Kinetics of nitrogen-15 labeled ammonium uptake by Caulerpa cupressoides (Chlorophyta). J Phycol 21:287-296

Submitted: January 12, 2004; Accepted: December 14, 2004 Proofs received from author(s): May 14, 2005 